\title{
Dawny kamieniołom Libana w Krakowie w kontekście planowanej rewaloryzacji
}

\author{
Marzanna Jagiełło \\ marzanna.jagiello@pwr.edu.pl \\ Wydziat Architektury, Politechnika Wroctawska \\ Bogusław Wowrzeczka \\ boguslaw.wowrzeczka@pwr.edu.pl \\ Wydziat Architektury, Politechnika Wroctawska
}

\section{Historia}

Podgórze, na którym usytuowany jest kamieniołom Libana, powstało w 1784 r. w wyniku nadania przez Józefa Il praw wolnego miasta wraz z nazwą - Josefstadt, przywilejami (m.in. zwolnieniem podatkowym) oraz własnym herbem. Okazało się ono ziemią obiecaną dla wielu przedsiębiorczych ludzi różnych narodowości i wyznań. Dogodne okoliczności - bliskość Krakowa, położenie przy rzece i zarazem linii kolejowej (od 1856 r.), a zarazem wyjątkowe warunki naturalne (wapienne wzgórza Krzemionek Podgórskich, stanowiące zaplecze surowcowe) sprawiły, że jego mieszkańcy przekształcili niewielką osadę w prężnie działające, nowoczesne pod względem przemysłowym miasto, połączone z Krakowem nowym mostem, a od 1900 r. zasilane w prąd z własnej (starszej od krakowskiej o 5 lat!) elektrowni miejskiej. Na jego teren przeniesiono także szereg zakładów z samego Krakowa.

W 1915 r. doszło do połączenia Krakowa z Podgórzem. Kolejne lata upłynęły jako okres integracji obu miast. Dziś, razem z Płaszowem, Rybitwami i Przewozem stanowi ono XIII dzielnicę Krakowa.

Tradycja pozyskiwania na Krzemionkach (nazwa ta pochodzi od licznie występujących w wapieniach krzemieni, których wydobycie rozpoczęło się wraz osadnictwem, począwszy od paleolitu) kamienia budowlanego i wypalania wapna sięga średniowiecza. Z wielu kamieniołomów już w XIV w. pozyskiwano wapienie jurajskie i margle senonu. Stanowiły one zaplecze budowlane Krakowa; odnajdziemy je w większości najbardziej znanych budowli. Intensywnie przemysł ten rozwinął się w drugiej połowie XIX w. Tutejszy wapień wykorzystywano także w przemyśle chemicznym, margle służyły do produkcji cementu, a iły do wyrobu cegieł.

W 1915 r. doszło do połączenia Krakowa z Podgórzem. Kolejne lata upłynęły jako okres integracji obu miast. Dziś, razem z Płaszowem, Rybitwami i Przewozem stanowi ono XIII dzielnicę Krakowa. Na jej terenie znajduje się m.in. dawny obóz pracy, od 1944 r. przekształcony w Konzentrationslager Plaszow bei Krakau, którego filią była fabryka Oskara Schindlera. Temu ostatniemu poświęcono, nakręcony w 1993 r., m.in. na terenie kamieniołomu Libana, film zat. Lista Schindlera. W 1994 roku, wraz z Wawelem, Kazimierzem, Starym Miastem, Nowym Miastem, Stradomiem i Piaskiem uznane zostało za Pomnik Historii.

Uwagę zwracają także walory krajobrazowe Podgórza. To stąd rozciąga się najpiękniejszy widok na Kraków, doceniony już w XVI w., z tego bowiem miejsca wykonano pochodzącą z lat 1536/37 najstarszą panoramę ówczesnej stolicy Polski. W pobliżu Kopca Krakusa, w miejscu innego podgórskiego kamieniołomu znajduje się także jeden z pięciu na terenie Krakowa obszarów chronionych, utworzony w 1961 r. Rezerwat Przyrody Nieożywionej Bonarka.

W centrum Krzemionek Pogórskich, tuż obok Kopca Krakusa znajduje się kamieniołom Libana, najbardziej rozległe (ok. 18 hektarów) i najgłębsze wyrobisko odkrywkowe obecnego Krakowa. Osady je tworzące pochodzą z okresu kredy. 


\section{Właściciele}

Nowy rozdział w historii Podgórza rozpoczął się w 1873 r., kiedy właścicielem jednego z podgórskich kamieniołomów, położonego obok Kopca Krakusa, został Bernard Liban, syn Judy Libana i Racheli, urodzony w Podgórzu 9 lutego 1848 r. Z wykształcenia był chemikiem. Ukończył studia w Instytucie Technicznym w Krakowie. Poza kamieniołomem posiadał na Podgórzu także wytwórnię gipsu („Bernard Liban Wyrób Gipsu Wszelkiego Rodzaju") a na terenie Borka Fałęckiego założoną w 1888 r. "Farbrykę Portland-Cementu Bernarda Libana". Na początku XX w. zatrudniała ona pół tysiąca pracowników. Został przejęta w 1937 r. od spadkobierców Libana przez należące do belgijskiego właściciela Ernesta Solvaya Krakowskie Zakłady "Solvay".

Kolejne inwestycje przemysłowe Bernarda Libana to, założona w 1906 r., wraz z bratem Władysławem na terenie Borku Fałęckiego, Farbryka Produktów Chemicznych "Liban” S.A. wytwarzająca nawozy sztuczne, oraz Fabryka Sody Amoniakalnej S.A., w 1909 r. przejęta przez koncern „Solvay" i przekształcona na Austriackie Zakłady Solvay - Fabryka Sody w Podgórzu.

Bernard Liban był także utalentowanym konstruktorem. Opatentował (w Anglii, Austrii, Francji, Rosji i na Węgrzech) piec szybowy w ruchu ciągłym oraz młyn żarnowy o dwu biegunach (w Niemczech).

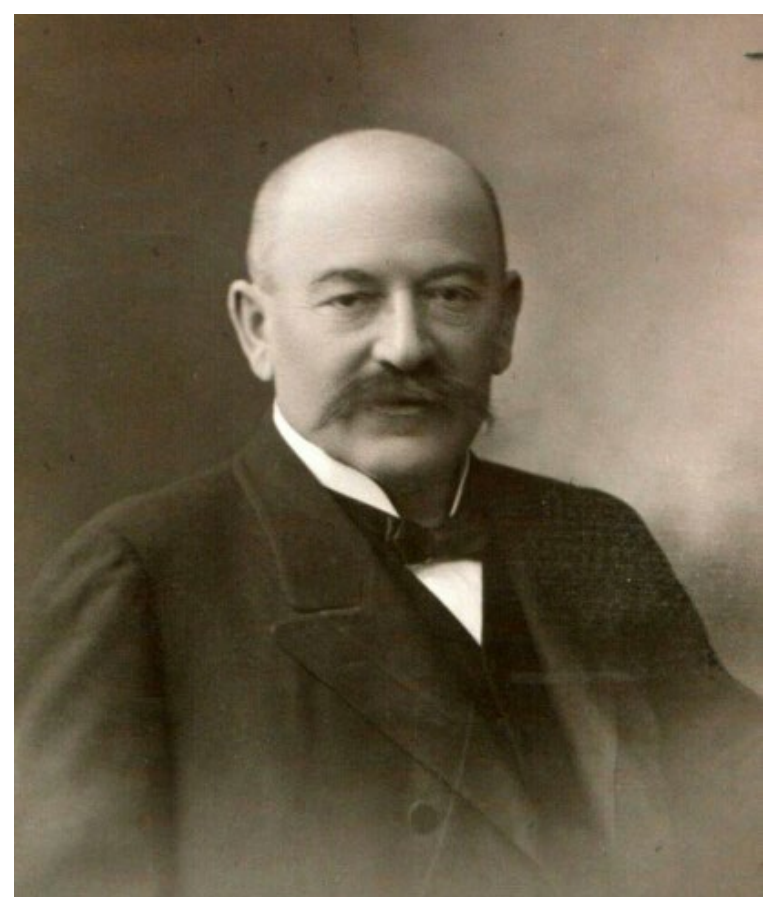

Ryc. 1. Bernard Liban. Fot. b.d. Zbiory Archiwum Narodowego w Krakowie NK, sygn. A-I-186).

Za: http://www.ank.gov.pl/podgorze/thumb/t_il_ludzie_64.jpg

Bernard Liban zmarł 23 maja 1916 r. w Wiedniu. Został pochowany na Pogórzu. Jego majątek rozdzielono między żonę oraz jedenaścioro dzieci. W ich imieniu (tzw. grupa Liban) spadkobierców reprezentował jeden z synów, Jan Liban.

\section{Historia kamieniołomu}

Firma założona w 1873 r. przez Bernarda Libana w kamieniołomie położonym obok kopca Krakusa rozpoczęła działalność pod szyldem Wapienniki i Kamieniołomy „Liban \& Ehrenpreis”. W krótkim czasie zbudowano zespół obiektów przemysłowych (oraz pomocniczych: warsztaty, magazyny, itp.) oraz budynków przeznaczonych na cele biurowe, socjalne (dla pracowników), a także mieszkalne. Wejście na teren kamieniołomu znajdowało się w miejscu zwanym w literaturze geologicznej jako łom „Za Torem", przy ulicy o tej samej nazwie, tuz obok budynku zachowanej do dzisiaj sztygarówki. Na terenie przedsiębiorstwa Libana produkowano wapno budowlane oraz nawozowe, pozyskiwano także kamień budowlany. 
Pod koniec XIX w. kamieniołom i wapienniki Libana i Ehrenpreisa stanowiły najważniejsze przedsiębiorstwo w branży materiałów budowlanych w Krakowie, dzieląc rynek zbytu z położonymi nieopodal Kamieniołami i Wapiennikami Miejskimi.

W 1894 r. kamieniołom połączono za pomocą bocznicy kolejowej ze stacją Podgórze-Bonarka. Około roku 1895 ustawiono po wschodniej stronie kamieniołomu, tuż przy ścianie piece pierścieniowe i piece Rumfolda, przeznaczone do wypalania wapna.

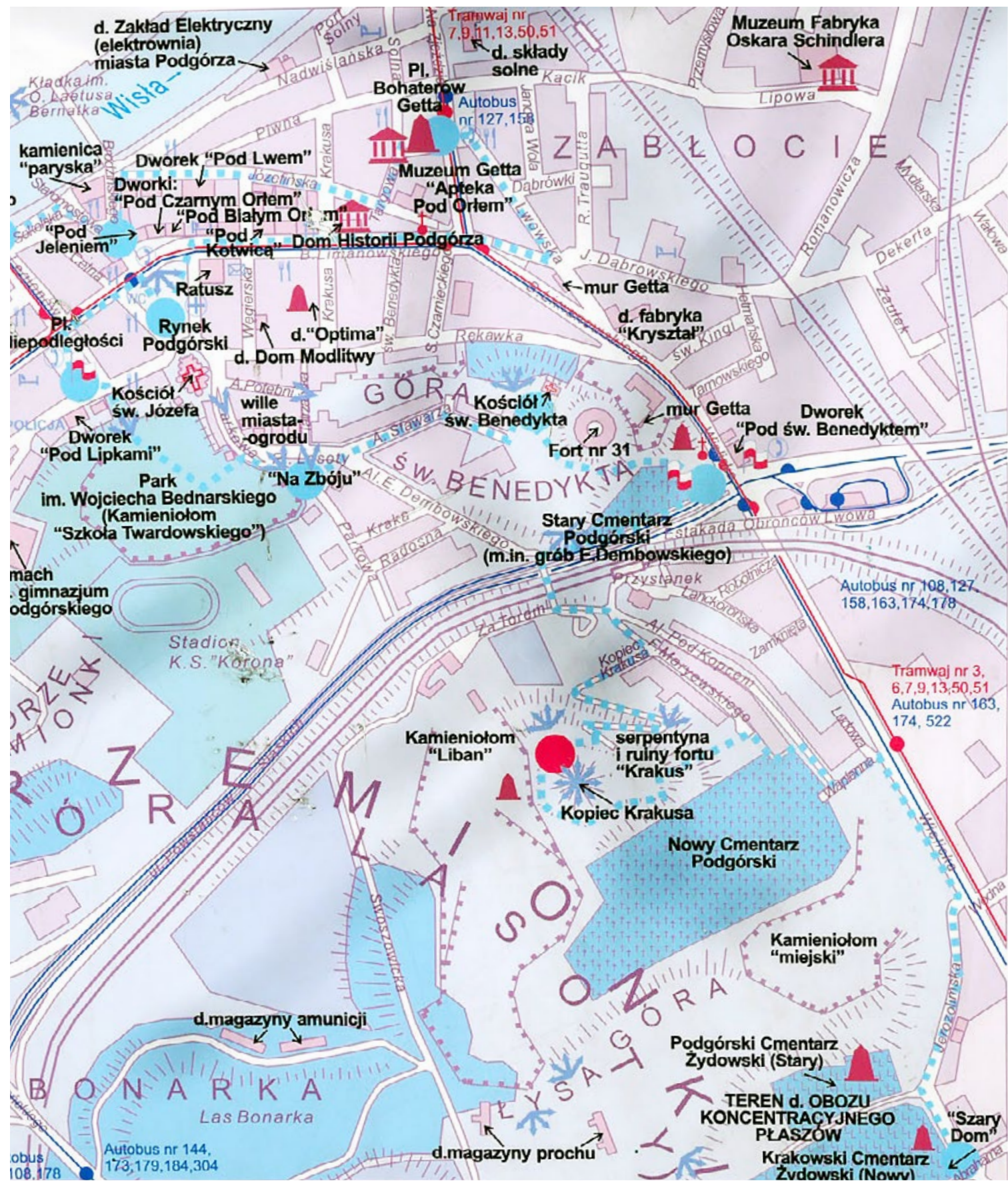

Ryc. 2. Podgórze wraz z dawnym kamieniołomem Libana i towarzyszących mu m.in.: Kopcem Krakusa, rezerwatem Bonarka, terenem dawnego obozu koncentracyjnego Płaszów i dwoma cmentarzami (komunalnym i żydowskim). Fragment tablicy informacyjnej na Kopcu Krakusa. Fot. B. Wowrzeczka, 2017. 
W okresie II wojny wyrobisko zostało przejęte przez administrację okupacyjną i zamienione w obóz pracy przymusowej (niem. Straflager des Baudienstes im Generalgouvernement) działający w latach 1942-1944. Pracowało w nim, w morderczych warunkach od 100 do 800 osób (w sumie ok. 2 tys.), Polaków i Ukraińców.

W czasie likwidacji obozu rozstrzelano 21 więźniów; miejsce ich egzekucji zostało upamiętnione w 1948 r. pomnikiem.

Kamieniołom został upaństwowiony w 1945 r. jako „Krakowskie Wapienniki i Kamieniołomy S.A." Zatrudniały one początkowo 230 osób pracujących m.in. przy trzech piecach kręgowych, które jednak zostały wyburzone, a na ich miejscu w latach 1971-1972 wzniesiono, zachowane do dzisiaj, piece szybowe. W 1977 r. zmieniono nazwę zakładu na Krakowski Kombinat Cementowo-Wapienniczy, Wydział Wapna (Wapiennik - Liban), który zatrudniał ok. 110 osób, a od 1981 r. występowa on jako Krakowski Kombinat Cementowo-Wapienniczy "Cementownia Nowa Huta, Wydział Wapna". Kamieniołom był eksploatowany do 1986 r. Pozostało po nim wyrobisko o powierzchni około 18 hektarów o wysokości ścian wahających się od 18 do 38 metrów, z dnem zawieszonym na wysokości 213-223 metrów n.p.m. W ostatnich latach łoże eksploatowano przy pomocy materiałów wybuchowych, co stanowiło duże obciążenie dla środowiska (drgania sejsmiczne, zanieczyszczenie powietrza spowodowane wypałem wapna).

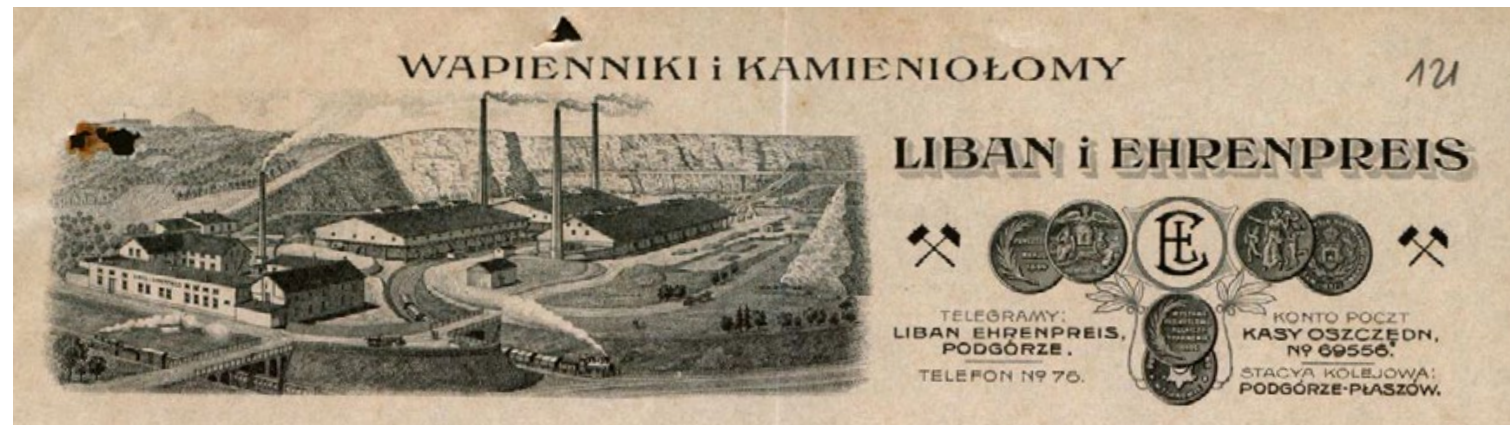

Ryc. 3. Winieta firmy "Liban \& Ehrenpreis" z widokiem zabudowań biurowo-mieszkalnych po stronie lewej i fabrycznych (piece wapienne kręgowe), warsztaty i bocznica kolejowa obsługująca fabrykę. Dokument datowany na $1916 \mathrm{r}$.

Za: http://podgorze.pl/wp-content/gallery/stare-dokumenty/30.jpg [data dostępu: 12.07.2017].

Pierwsze projekty dotyczące rekultywacji terenu wykonano już w 1974 r. (ANK, sygn. WAP ul. Za Torem 22, P 156 (nr 7140). Zamierzano na jego terenie urządzić „Podgórski Zespół Wypoczynkowy”. Przygotowana koncepcja obejmowała uruchomienie kąpieliska w otoczeniu terenów rekreacyjnych. Projekt ten nie został jednak zrealizowany, a teren wyrobiska przejęło w 1988 r. Przedsiębiorstwo Gospodarki Komunalnej.

Po zakończeniu eksploatacji w 1986 r. kamieniołom Libana stał się, w wyniku sukcesji naturalnej, ostoją przyrody położoną w centrum miasta, przewyższającą powierzchnią tereny zielone znajdujące się na terenie innych dzielnic Krakowa. Dno kamieniołomu wypełnia częściowo woda, tworząca okresowo zanikające stawy, z których korzysta wiele gatunków ptaków (m.in. łyski, kaczki krzyżówki, czernice, głowienki) oraz płazów (jaszczurki zwinki, padalce).

Cenne są również rosnące tu rośliny. Pośród nich wodne oraz światłolubne i wapieniolubne, głownie naskalne, m.in. murawy kserotermiczne, które rozwijają się na nasłonecznionych zboczach na suchym podłożu wapiennym; stanowią one siedlisko motyli.

W 2002 r. teren kamieniołomu Liban objęła swoim działaniem (wraz z Rezerwatem Przyrody Nieożywionej Bonarka, terenem byłego obozu koncentracyjnego „Płaszów”, otoczeniem Kopca Krakusa i Laskiem Bonarka) fundacja Centrum Edukacji Kulturowej i Ekologicznej, funkcjonujące na obszarze Krzemionek Podgórskich. Została ona powołana do życia Uchwałą Zarządu Miasta Krakowa. Celem zainicjowanego przez Centrum projektu było uporządkowanie i ochrona miejsc męczeństwa, wartości przyrodniczych i historycznych oraz wykorzystanie możliwości rekreacyjnych tego obszaru, uwzględniających martyrologiczną część jego historii. Brak funduszy, nieporozumienia we współpracy z miastem doprowadziły jednak do rozwiązania w 2008 r. budzącej od początku wiele emocji fundacji. 
Z dawnego kompleksu fabrycznego zachowały się do dzisiaj następujące, obiekty: budynek zwany sztygarówką, położona nieopodal niego niewielka kotłownia z wysokim, ceglanym kominem, hale mieszczące niegdyś piece do wypalania wapna, budynek pełniący funkcję kuźni, a na terenie wyrobiska cztery stalowe młyny wapienne. Nie zachowały się niestety żadne projekty dotyczące tych obiektów. O ich pierwotnym wyglądzie informują nas bardzo ogólnie tylko stare fotografie (pocztowe) oraz winiety papierów firmowych spółki, pochodzące z początku XX w.

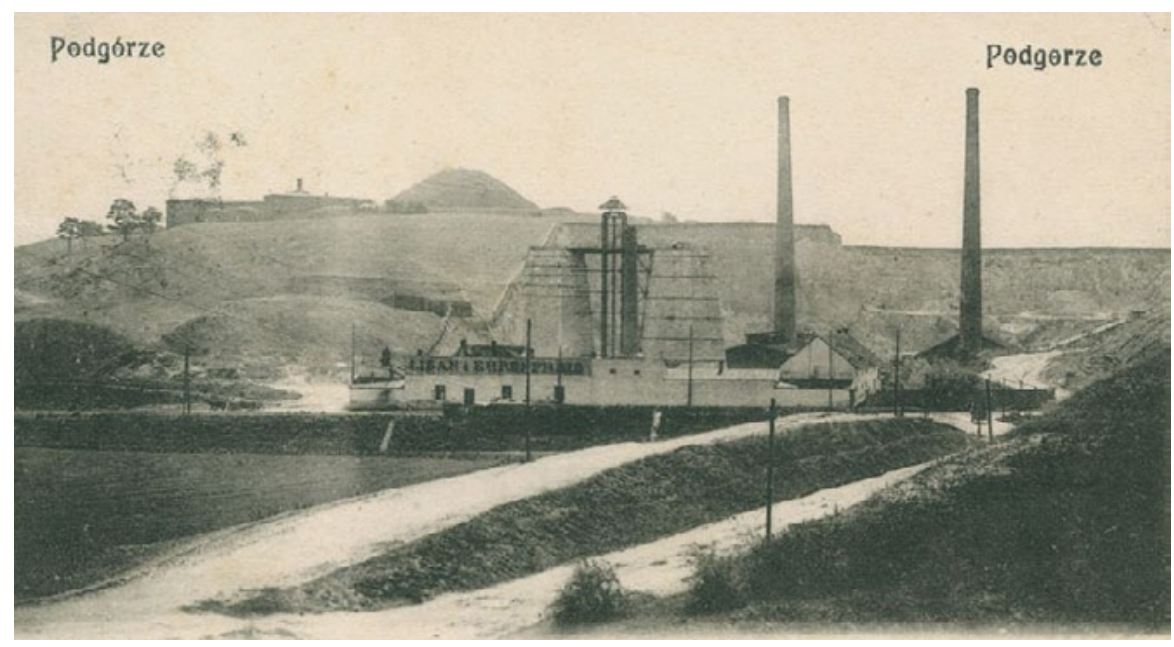

Ryc. 4. Pocztówka z Pogórza z widokiem wapienników Rumforda (na pierwszym planie) w kamieniołomie firmy „Liban \& Ehrenpreis", w głębi Kopiec Krakusa. Fot. z początku XX w.

Za: http://podgorze.pl/wp-content/gallery/dawne-widokowki/33.jpg [data dostępu: 12.07.2017].

Obecnie kamieniołom znajduje się pod opieką Zarządu Zieleni Miejskiej. Jest źle zabezpieczony, a pozostałości obiektów przemysłowych ulegają postępującemu zniszczeniu, stanowiąc jednocześnie zagrożenie dla osób przedostających się nielegalnie, ale z wielką łatwością, na teren tego niezwykłego miejsca.

Nie zachowały się niestety żadne projekty dotyczące budynków powstałych na terenie kamieniołomu Libana. W Archiwum Narodowym w Krakowie przechowywany jest jedynie rysunek przedstawiający rozprowadzenie instalacji wodociągowej „w zakładzie fabrycznym firmy Liban \& Ehrenprais” z 1913 r. (sygn. NAK, ABM, ul. Za Torem 22 F. 1029 a), obejmujące warsztaty, piece wapienne, kotłownie oraz budynek dawnej sztygarówki.

Z dołączonego do projektu planu wynika, że sztygarówka funkcjonowała w zwartym kompleksie budynków zlokalizowanych przy "drodze do przystanku Podgórze miasto" i zarazem przy "CK kolei państwowej” (informacja z planu), a jednocześnie zgrupowanych wokół stosunkowo niewielkiego dziedzińca.

\section{Ogólna koncepcja konserwatorska}

Wszystkie wspomniane budynki zachowane na terenie kamieniołomu znajdują się obecnie w bardzo złym stanie technicznym, sugerującym raczej rozbiórkę, o tyle bardziej, że nie reprezentują one szczególnych walorów architektonicznych. Są one cenne z przyczyn historycznych, sentymentalnych, także jako świadectwo przemysłowego rozwoju Podgórza. Budynek sztygarówki oraz komin dawnej kotłowni, z racji swojej lokalizacji mogą w związku z tym stanowić funkcjonalno-symboliczną zapowiedź tego, co znajduje się na pozostałym, położonym dalej od głównej trasy komunikacyjnej, terenie dawnego kamieniołomu. Są ważne ze względu na wartość otoczenia, z którym wiążą je wspólne, fascynujące, ale i dramatyczne dzieje. Na to wielowątkowe znaczenie kontekstu składają się następujące, splecione ze sobą na tym obszarze aspekty:
a. historyczno-industrialny;
b. geologiczny;
c. przyrodniczo-krajobrazowy;
d. martyrologiczny;
e. sportowo-rekreacyjny. 
Podgórskie kamieniołomy miały przez stulecia ogromne znaczenie gospodarcze, do którego dołączyć należy szczególnego rodzaju walory krajobrazotwórcze (ściany, zwałowiska, punkty widokowe, zbiorniki wodne). Stanowią z jednej strony świadectwo dziedzictwa przemysłowego tego obszaru, dokumentują historię górnictwa skalnego. Z drugiej zaś stanowią trwały element dziedzictwa geologicznego. A różnorodność utworów geologicznych, ich dostępność do bezpośredniej obserwacji stwarza wyjątkowe warunki do realizowania na tym terenie celów dydaktycznych. Znaczącą wartością są także ślady dawnej eksploatacji zachowane na ścianach, będące świadectwem dawnych metod kopalnianych.

Wpisanie dawnego kamieniołomu Libana w ciąg tras geoturystycznych, mogłoby znacząco wzbogacić ofertę turystyczną Krakowa, o tyle bardziej, że położony jest on blisko centrum, zapewniając jednocześnie najpiękniejsze i najpełniejsze widoki całego miasta.

Uwagę zwraca także wielka różnorodność i bogactwo świata organicznego, co jest właściwością niemal wszystkich dawnych wyrobisk pogórniczych, na co wskazują badania biologów i ekologów. Tworzą się w tym miejscu samoistne (na zasadach sukcesji naturalnej) ostoje flory i fauny obfitujące w gatunki rzadkie i chronione. Kompleksowa rewitalizacja Krzemionek Podgórskich, w tym dawnego kamieniołomu Libana powinna zatem uwzględnić wszystkie zjawiska przyrodnicze, które są następstwem postępującej na tym obszarze sukcesji naturalnej. Godne podkreślenia są także walory rekreacyjne tego miejsca, np. ściany wspinaczkowe (obecnie funkcjonuje kilka z nich). Całość tworzy oazę ciszy i spokoju w centrum ruchliwego, zanieczyszczonego w znacznym stopniu miasta.

Dziś miejsce to stanowi rodzaj krajobrazu antropogenicznego o szczególnego rodzaju właściwościach, swoistości i odrębności. Na jego percepcję może mieć wpływ upowszechnienie walorów przyrodniczych i kulturowych kamieniołomów, co staje się domeną działań związanych z adaptacją terenów poprzemysłowych określanych jako econvention (ecology + invention). Kierunek ten, wykorzystując nowoczesne metody, strategie i technologie promuje przywracanie "do życia” obszarów straconych, zdegradowanych poprzez adaptację podporządkowaną różnym celom publicznym: edukacyjnym, rekreacyjnym, wystawienniczym, sportowym, itp. Warto również pamiętać, że coraz częściej obiekty te traktowane są jako element europejskiego dziedzictwa kulturowego, związanego z ważnym etapem rozwoju cywilizacyjnego człowieka. Przykładów na takie podejście do zagadnień związanych z dawnymi wyrobiskami jest w Europie wiele (np. Niemcy - Horka, Prelle, Wetro; Austria - Sankt Margarethen im Burgenland; Wielka Brytania - Eden Project; Chiny - Quarry Garden w Ogrodzie Botanicznym w Szanghaju; Australia - ogród Botaniczny w Melbourne). Zmiany w podejściu do zagospodarowania dawnych wyrobisk obserwujemy także w Polsce, czego przykładami choćby "Wzgórza Paciorkowców” w Bieruniu, a z ostatnich lat kamieniołom Kadzielnia na obrzeżach Kielc, czy geopark Glinka w Ujsołach.

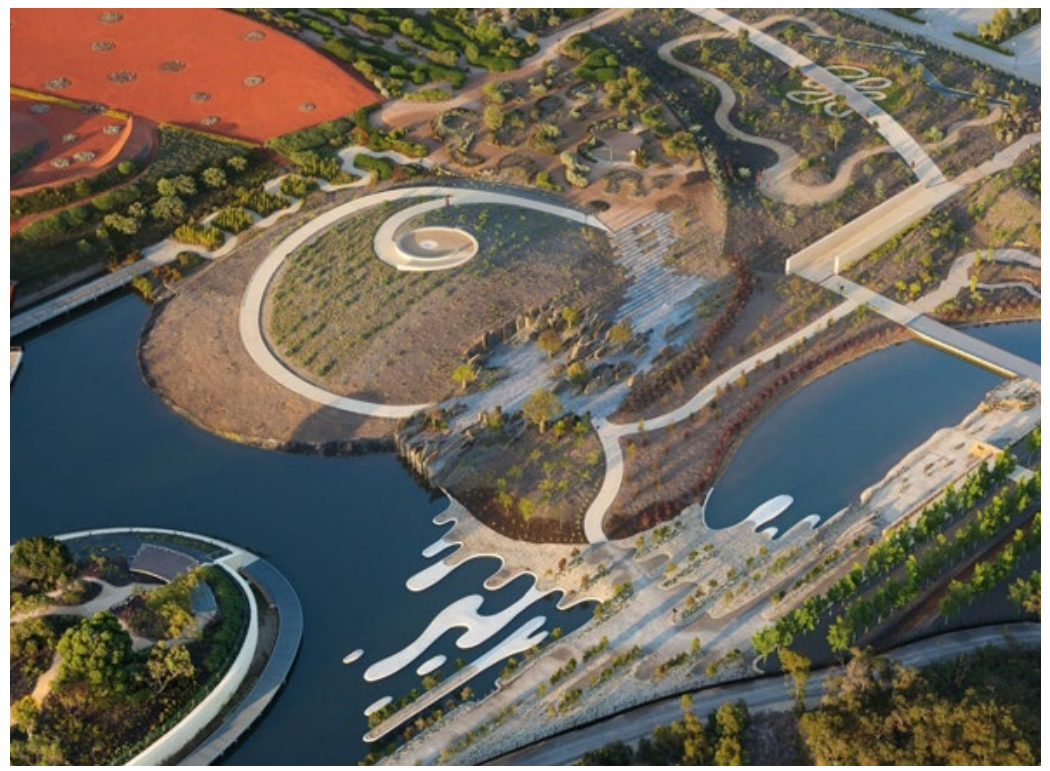

Ryc. 5. Ogród Botaniczny w Cranbourne, na południowo-wschodnich obrzeżach Melbourne (The Royal Botanic Garden), na terenie dawnego wyrobiska kopalni piasku. Proj. Taylor Cullity Lethlean oraz ekspert zieleni Paul Thompson.

Fot. John Gollings, 2012 Za: http:// aasarchitecture.com/2013/07/the-australian-garden-by-taylor-cullity-lethlean-and-paul-thompson.html [data dostępu: 20.05.2018] 


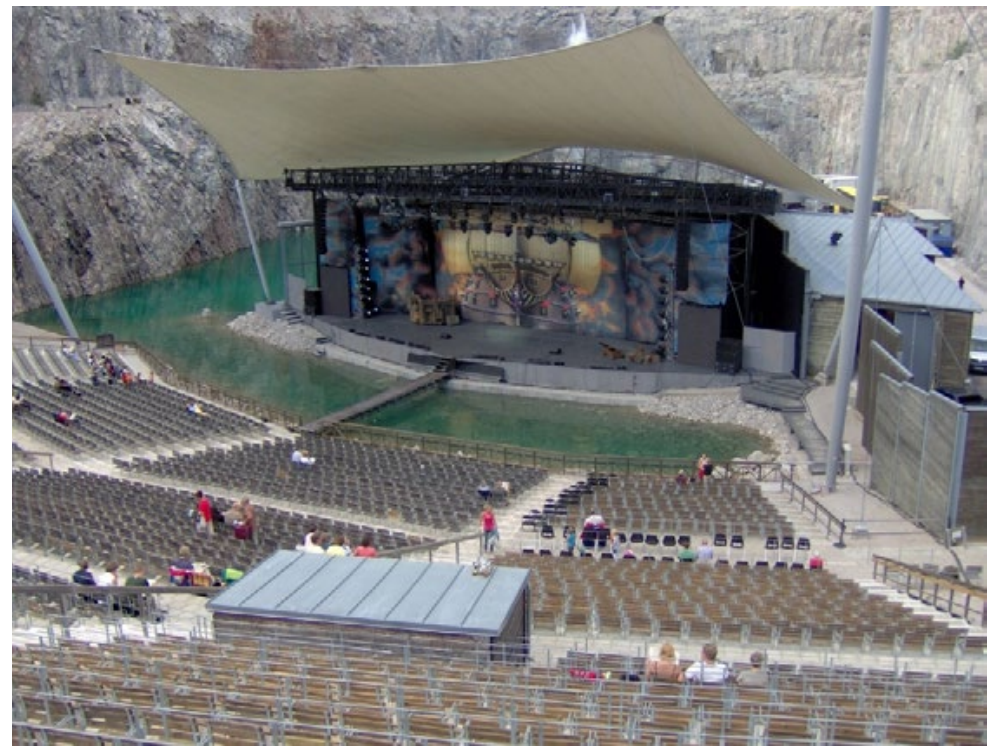

Ryc. 6. Amfiteatr w Dalarna w środkowej Szwecji znajduje się $w$ dawnym kamieniołomie wapienia i służy jako letni teatr muzyczny. Fot. Johannes Scherman, 2007.

Za: https://en.wikipedia.org/wiki/Dalhalla [data dostępu: 20.05.2018]

Ze względu na wspomnianą wieloaspektowość funkcjonowania tego typu terenów niezbędnym jest wykonanie, poprzedzające wszelkie decyzje i działania: studium krajobrazowego i geośrodowiskowego (opinie geologów, geomorfologów) i badań przyrodniczych. Dobór odpowiedniego kierunku przekształceń powinien zostać poprzedzony dogłębną analizą otoczenia, uwzględniającą zarówno czynniki ekonomiczne i formalno-prawne, jak i uwarunkowania geologiczno-inżynierskie, hydrologiczne, historyczno-kulturowe, przestrzenne, społeczne oraz środowiskowe. Ich wyniki pozwolą na wybór najwłaściwszego kierunku adaptacji obszaru poeksploatacyjnego.

Dodatkowym walorem tego miejsca jest bliskość Kopca Krakusa, który poza właściwymi sobie walorami i historią, stanowi również znakomity punkt widokowy, z którego roztacza się panorama Krakowa, a przy dobrej pogodzie widoczne bywają nawet Tatry. Można z niego oglądać także wnętrze oraz otoczenie kamieniołomu Libana.

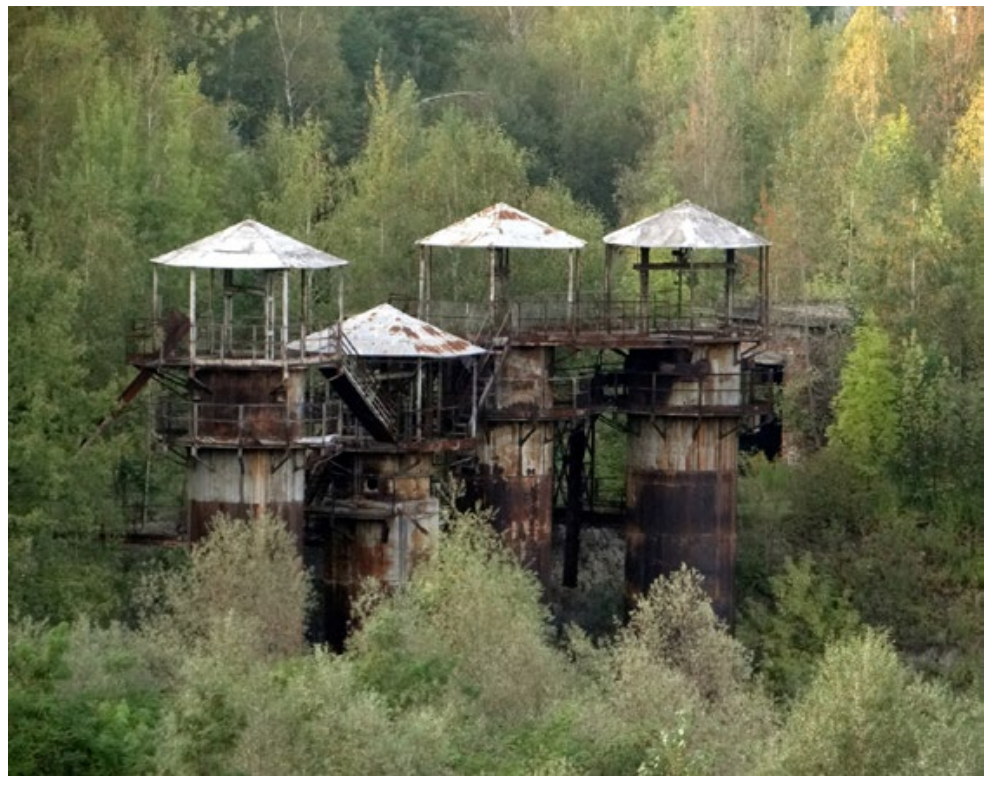

Ryc. 7. Młyny do mielenia wapieni w wyrobisku dawnego kamieniołomu Libana. Fot. Zbigniew Czernik, 2016.

Za: https://upload.wikimedia.org/wikipedia/commons/b/b8/Krak\%C3\%B3w_-_ kamienio\%C5\%82om_Libana.jpg [data dostępu: 20.05.2018]

W zespole tym znaczące miejsce może zająć budynek dawnej sztygarówki, otwierający trasę turystyczną od strony ul. Za Torem, w którym mogłoby znaleźć siedzibę muzeum (co odpowiada zapisom MPZP, par. 42, 
art. 1-3) prezentujące historię dziedzictwa industrialnego Podgórza i pełniące zarazem rolę miejsca popularyzacji nieczynnych kamieniołomów, jako obiektów geoturystycznych. Jest to obiekt predestynowany do takiej funkcji, zwłaszcza w kontekście eksponującego go od niedawna usytuowania, co stało się udziałem tego obiektu po wybudowaniu nowej arterii samochodowej biegnącej aleją Powstańców Śląskich, stanowiącą część tzw. Il obwodnicy Krakowa. Komin znajdującej się obok kotłowni nabiera w jego otoczeniu szczególnego znaczenia, jako symboliczny relikt infrastruktury przemysłowej, dzięki której Podgórze osiągnęło w 2. poł. XIX w. swój dobrobyt i status, podobnie, jak pozostałe budynki, które mogłyby zostać zaadaptowane do potrzeb związanych z innymi wprowadzanymi na teren kamieniołomu funkcjami.

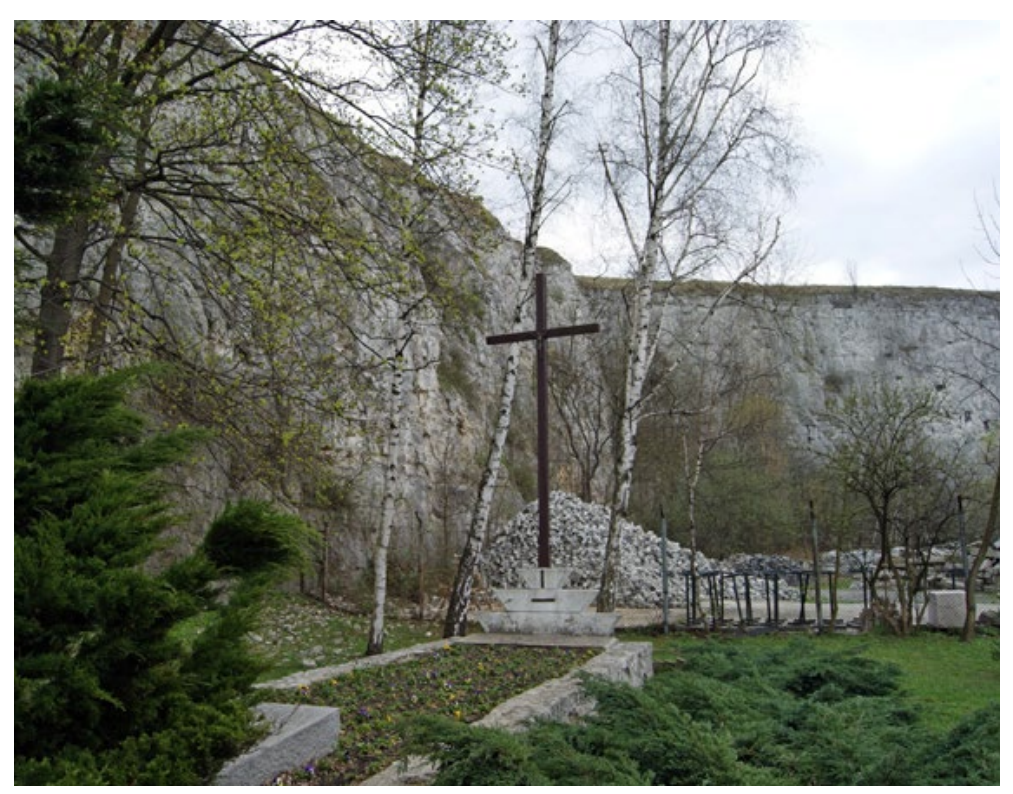

Ryc. 8. Cmentarz rozstrzelanych więźniów pracujących w czasie II wojny za terenie kamieniołomu Libana. Fot. Zygmunt Put, 2011.

Za: https://upload.wikimedia.org/ wikipedia/commons/thumb/8/87/ Liban\%27s_Quarry\%2C_former_WWII_ German_Nazi_Labour_Camp\%2C_cemetery_of_executed_prisoners\%2C_Za_Torem_street\%2C_Krakow\%2C_Poland.jpg [data dostępu: 20.05.2018]

Ważnym elementem, związanym z kamieniołomem jest martyrologiczna część jego wojennej historii. Z tej przyczyny cześć muzealnej ekspozycji urządzonej w sztygarówce mogłaby nawiązywać do dramatycznej historii tego miejsca a całość uwzględniać jego kontemplacyjny charakter.

Taka adaptacja dawnych kamieniołomów Libana stworzyłyby grunt dla ożywienia turystycznego tej części Krakowa, ciągle jeszcze nie w pełni pod tym względem wypromowanej i wykorzystanej (na jednej z żartobliwych internetowych map miasta gdzie zamieszczono nowe nazwy dla poszczególnych dzielnic, teren związany z kamieniołomem Libana określono jako "Czarną dziurę").

Pilna decyzja dotycząca losów dawnego kamieniołomu Libana wydaje się o tyle ważna, że ten atrakcyjny pod wieloma względami teren, pozbawiony w zasadzie efektywnej opieki, staje się coraz bardziej niebezpieczny.

\section{W opracowaniu wykorzystano}

[1] Anna AGACIAK, Podgórskie Krzemionki straca gospodarza?, [w:] „Polska Gazeta Krakowska”, 10.04.2008.

[2] Monika DOLEGŁO, Przyrodnicze i historyczne uwarunkowania rozwoju krakowskiego Podgórza jako czynnik rewitalizacji, [w:] „Przestrzeń i Forma”, czasopismo PAN, z. 2, 2015, s. 191-411.

[3] Maciej GLINIAK, Liban' Quarry - Education Path Promoting Conservation Traces of Former Opencast Mining, [w:] "Inżynieria Mineralna" 2015, Tom: 1, Z.: 35, s. 121-126. Za: https://repo.ur.krakow.pl/info/article/UR2e0382eaf666416aa35a3224fccb843b. [data dostępu: 10.05.2017]

[4] Maciej GLINIAK, Projekt rewitalizacji miejskich terenów pogórniczych na przykładzie kamieniołomu "Liban" w Krakowie, [w:] „Młodzi naukowcy dla Polskiej Nauki, cz. 8. Nauki Przyrodnicze”, T. 4, Kraków 21012, s. 137-141.

[5] Jerzy GÓRECKI, Edyta SERMET, Kamieniołomy Krakowa - dziedzictwo nieocenione, [w:] „Dzieje górnictwa - element europejskiego dziedzictwa kultury", z. 3, (red.) P.P. Zagożdżon, M. Magdziarz, Wrocław 2010, s. 12-138. 
[6] Aleksander GURGUL, Studenci z Edynburga szukaja pomysłów na kamieniołom Libana, [w:] "Gazeta Wyborcza.Kraków”, 30.09.2015.

[7] Marzanna JAGIEŁŁO, Bogusław WOWRZECZKA, Waldemar BOBER, Kajetan SADOWSKI, Dokumentacja Konserwatorska określająca stan zachowania obiektów "Sztygarówki” oraz dawnej kotłowni z kominem, położonych w Krakowie, przy ulicy Za Torem 22. Wnioski i wytyczne do opracowania programu konserwatorskiego, Wrocław 2017;

[8] opracowanie wykonane na zlecenie Gminy Miejskiej Kraków, Zarząd Zieleni Miejskiej w Krakowie.

[9] Roman KIEŁKOWSKI, Historie spod Kopca Krakusa, Kraków 1972.

[10] Agnieszka LISOWSKA, Zagospodarowanie dużych form przeksztatcenia krajobrazu na cele turystyki-na wybranych przykładach, [w:] „Turystyka kulturowa”, nr 5/2015, s. 55-76.

[11] Zbigniew MYCZKOWSKI, Studia i aranżacje krajobrazowe wybranych obiektów poeksploatacyjnych, [w:] „Kształtowanie krajobrazu terenów poeksploatacyjnych".Materiały Międzynarodowej Konferencji organizowanej przez Akademię Górniczo-Hutniczą i Politechnikę Krakowską, Kraków 2003, s. 87-100.

[12] Jerzy NITA, Urszula MYGA-PIĄTEK, Krajobrazowe kierunki zagospodarowania terenów pogórniczych, [w:] „Przegląd Geologiczny", 2006, vol. 54, nr 3, s. 256-262.

[13] Anna OSTRĘGA, Zagospodarowanie kamieniołomu Libana z uwzględnieniem jego losów wojennych oraz sąiedztwa terenu byłego $K L$ "Płaszów" - Management of Libana quarry taking into account its war past and neighborhood of former KL "Plaszow", [w:] "Górnictwo Odkrywkowe", R. 2001, z. 43, nr 6, s. 51-60.

[14] Anna OSTRĘGA, Sposoby zagospodarowania wyrobisk i terenów po eksploatacji złóż surowców węglanowych na przykładzie Krzemionek Podgórskich w Krakowie, mps pracy dr. AGH, Kraków 2004.

[15] Małgorzata SZCZEPAŃSKA, Charakterystyka geologiczna starych wyrobisk górniczych Krzemionek Podgórskich, [w:] "Technika Poszukiwań Geologicznych", nr 6/2005, s. 35-45.

[16] Agata ZACHARIASZ, Park w kamieniołomie, [w:] „Kształtowanie krajobrazu terenów poeksploatacyjnych”, Materiały Międzynarodowej Konferencji organizowanej przez Akademię Górniczo-Hutniczą i Politechnikę Krakowską, Kraków2003, s. $102-111$.

[17] Leszek ZACHUTA, Historia Fabryki Portland-Cementu Bernerda Libana, [w:] Cement Wapno Beton, 2001, R. 6/68, nr 2, s. 71-77.

\section{Źródła elektroniczne}

[18] http://podgorze.pl/kamieniolom-libana/ [data dostępu: 15.05.2017]

[19] http://poszli-pojechali.pl/europa/polska/krakow-na-wyrywki-kamieniolom-liban/ [data dostępu: 15.05.2017]

[20] http://wspinanie.pl/serwis/200907/08nasze-skaly-liban-porozumienie.pdf [data dostępu: 15.05.2017]

[21] http://wspinanie.pl/topo2/page,topo-rejony,rejon,172.html [data dostępu: 15.05.2017]

[22] http://krakow.naszemiasto.pl/artykul/sladami-historii-w-krakowie-byly-oboz-koncentracyjny-plaszow,2866112,artgal,t,id,tm. html [data dostępu: 15.05.2017]

[23] http://www.travelforum.pl/threads/1169-Krakowskie-Podg\%C3\%B3rze/page2 [data dostępu: 15.05.2017]

[24] http://docplayer.pl/12933122-Przyrodnicze-i-historyczne-uwarunkowania-rozwoju-krakowskiego-podgorza-jako-czynniki-rewitalizacji.html [data dostępu: 15.05.2017]

[25] http://docplayer.pl/2015577-Kamieniolomy-krakowa-dziedzictwo-niedocenione.html [data dostępu: 15.05.2017]

[26] http://www.krajobraz.kulturowy.us.edu.pl/publikacje.artykuły/23/11.nita.pdf [data dostępu: 15.05.2017]

[27] https://en.wikipedia.org/wiki/Dalhalla [data dostępu: 20.05.2017]

[28] http://aasarchitecture.com/2013/07/the-australian-garden-by-taylor-cullity-lethlean-and-paul-thompson.html [data dostępu: 20.05.2017] 